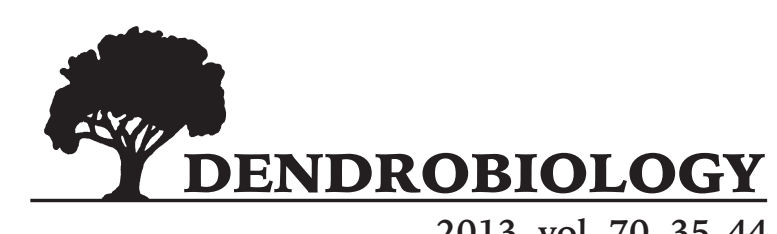

2013, vol. 70, 35-44

http://dx.doi.org/10.12657/denbio.070.004

\author{
František Krejčí, Stanislav Vacek, Lukáš Bílek*, Miroslav Mikeska, \\ Pavla Hejcmanová, Zdenek Vacek
}

\title{
The effects of climatic conditions and forest site types on disintegration rates in Picea abies occurring at the Modrava Peat Bogs in the Šumava National Park
}

Received: 21 September 2012; Accepted 30 January 2013

\begin{abstract}
A survey of mountain spruce stand development in the Šumava National Park on Modrava peat bogs on an area of 1,370 ha resulting from spruce bark beetle outbreaks was performed by means of visual evaluation of aerial photographs from the period 1991-2000. In addition, our study addressed the influence of climatic effects (period 1984-2000) and the effect of forest site (climax, waterlogged and peaty spruce stands) on the dynamics of disintegration of forest stands. We showed that new infestations were predominantly found at short distances from their source, the average value was estimated to be 40-60 m, whereas the longest distance for annual progress in west to east direction was estimated to be $120 \mathrm{~m}$. Differences in the dynamics of disintegration between waterlogged stands and drier stands were confirmed. There was a positive relationship between the average temperature in the $2^{\text {nd }}$ quarter of monitoring years which was registered as the period of the onset of bark beetle development and the proportion of degraded area in Norway spruce stands. Moreover, pronounced winter desiccation in January 1993 was a triggering mechanism with crucial importance for the outbreak of bark beetle in the studied area.
\end{abstract}

Additional key words: Šumava, Norway spruce, aerial survey photos, bark beetle outbreak, winter desiccation

Addresses: F. Krejčí, Administration of the National Park and Protective Landscape Area of Šumava, 1. máje 260, 38501 Vimperk, Czech Republic, S. Vacek, L. Bilek, M. Mikeska, P. Hejcmanová, Z. Vacek Czech University of Life Sciences in Prague, Faculty of Forestry and Wood Sciences, Kamýcká 129, 16521 Prague, Czech Republic, e-mail: bilek@fld.czu.cz

\section{Introduction}

Reserves and protected areas are an important part of any national strategy for conserving forest biodiversity including both, interventional and non-interventional management approaches. In the first case, differentiated polyfunctional management of forest ecosystems should lead to their higher ecologi- cal stability and diversity and to the development of near-natural methods of their management (cf. Korpel' 1993; Otto 1994; Jeník 1998; Poznański and Jaworski 2002; Vacek, Simon, Remeš et al. 2007). In the second case, ecological disturbance of different types and intensities often determines biophysical parameters, forest ecology and forest development in a particular area. Whether or not, and how, to incorpo- 
rate natural disturbance regimes in natural resource management is often complicated by competing values and perceptions from within the human dimensions of changing ecosystems (Flint et al. 2009).

Higher elevations of the Šumava National Park (Šumava NP) are dominated by sub-alpine spruce forests with Norway spruce (Picea abies /L./ Karst) (cf. Sofron 1980, Vacek et al. 2003). Their characteristics and development have often been evaluated and discussed in forestry literature (Svoboda and Pouska 2008; Vacek et al. 2009; Štícha et al. 2010; Svoboda et al. 2010). Forest stands in this area have suffered repeated epidemic outbreaks of spruce bark beetle (Ips typographus /L./), which can be considered as naturally occurring disturbance, nevertheless experts in various scientific disciplines (nature conservation, forest ecology, silviculture and forest management) are not unique in interpreting the forest development related to this type of damage and differ also in management approaches to forest stands in this area (cf. Vacek 2003). Moreover, ecological disturbances of forests by insects have a complex array of associated human dimensions presenting complications for natural resource decision making and relationships between stakeholders and managers (Flint et al. 2009).

Many authors studied the dynamics of natural forests in similar site and stand conditions (Schmidt-Vogt 1985; Hofgaard 1993; Průša 1985; Korpel' 1995; Saniga and Schütz 2001; Holeksa 2001; Vrška et al. 2001; Vacek 1990; Vacek et al. 2007; Svoboda 2005; Svoboda and Pouska 2008; Vacek et al. 2009; Svoboda et al. 2010; Pouska et al. 2010; Čížková et al. 2011). These studies indicated that pronounced differences in the development of mountain spruce stands are reflected first of all within different developmental stages and phases on different sites. Accelerated dynamics of development and sometimes of complete disintegration of mountain spruce stands is caused by wind, insects (bark beetles), pollutants, winter desiccation and often by the synergic action of all these factors resulting in "decline disease spiral" reflecting the cumulative, sequential contributions of various events and factors (Manion 1981). In mountain spruce stands in the Krkonoše Mts. it was a result of the common action of pollutants and winter desiccation (cf. Vacek et al. 2007) and in conditions of the Šumava Mts. it was probably a result of synergism of air pollution stress, climatic fluctuations and subsequent feeding of the spruce bark beetle in zones with no bark beetle control (Matějka 1994; Pfeffer and Skuhravý 1995; Skuhravý 2002; Vacek et al. 2003, 2006; Vacek et al. 2009).

The concept of using both aerial photographs and satellite remote sensing to assess the health status development of trees and forest stands in this region is not new. Hájek and Svoboda (2007) assessed bark beetle damage in the Trojmezná old-growth forest us- ing automated classification of aerial photographs and Zemek et al. (1999) used multispectral satellite data for quantification of spatial extents of forest cover changes as a result of bark beetle outbreak in the Šumava NP; in the Bavarian Forest National park were used the methods of object-based image analyses for the identification of bark beetle infested trees (Tiede et al. 2006; Heurich et al. 2010); Kautz et al. (2011) analysed a 22-year time series of colour-infrared (CIR) images of spatio-temporal dispersion of bark beetle infestations and developed a GIS-based distance radius approach to quantify the distance relation of subsequent infestations.

In the present paper the dynamics of mountain spruce stand development on Modrava peat bogs in the Šumava NP was evaluated on an area of 1,370 ha that was severely affected in the past by frequent disturbances, mainly by windthrow and bark beetle outbreaks (Skuhravý 1997). A general objective of this contribution was to describe accelerated disintegration of mountain spruce stands during the 1990s in a model territory between the mountains Luzný and Roklan. The main goal was to analyse the annual augmentation of areas of dry mature spruce trees based on a 10-year series of aerial survey photos (spectrozonal and multispectral ones) using methods in the GIS environment. Additionally, our study addressed the influence of climatic effects and the effect of forest site (climax, waterlogged and peaty spruce stands) on the dynamics of disintegration of spruce stands.

\section{Study area}

The described territory belongs to the Modrava peat bog complex in the central part of the Šumava NP (Fig. 1). The total area of former National Nature Reserve (NNR, declared in December 1989) was 3,600 ha. In 1991 this reserve was included in Nature Conservation Zone I in the newly declared Šumava NP. In 1995 this territory was declared as a silence area where the admission of the public is limited. The

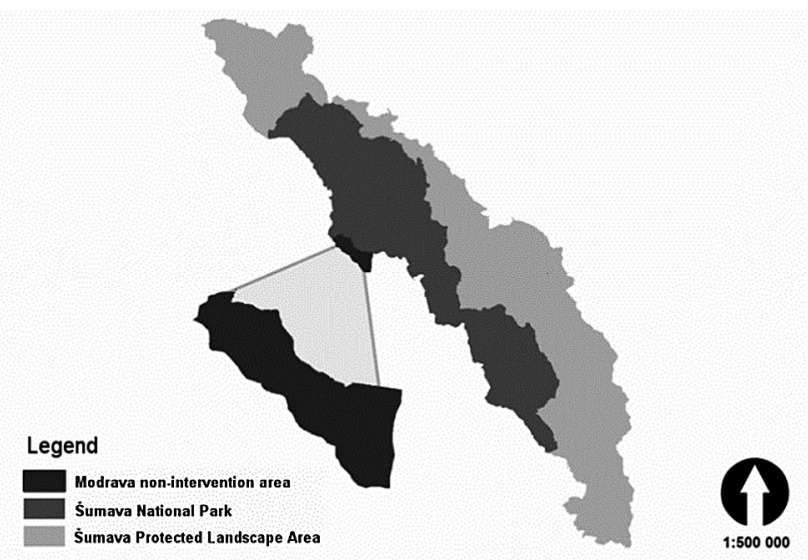

Fig. 1. Localization of the territory of interest on Modrava peat bogs 
whole complex is classified as wetlands protected by the Ramsar Convention. The varied mosaic pattern of mountain spruce stands and peat bogs has undergone highly accelerated development dynamics in the last 20 years.

Climatic conditions of the studied territory are similar to those of coniferous taiga in boreal forests (cf. Schmidt-Vogt 1986; Vacek et al. 2009). The climate of this territory belongs to the coldest and wettest climates in the Czech Republic. Long-term hydrometeorological measurements are done at Březník climate station at $1,135 \mathrm{~m}$ a.s.l. This altitude is approximately the lower border of the natural occurrence of mountain spruce stands in the Šumava Mts. Average annual temperature ranges between 3.5 and $3.7^{\circ} \mathrm{C}$. Snow cover reaches up to $3 \mathrm{~m}$ in the studied territory and lasts for 200 days. Spring is very short. The number of days with windstorm is up to 40 and the number of foggy days is 200 (Hais and Kučera 2008).

Nearly a half of the studied territory is covered by acidic mountain spruce stands and the other half is covered by a varied mosaic pattern of waterlogged and peaty spruce stands and peat bogs - swamps. The altitude ranges from 1,135 to $1,370 \mathrm{~m}$ a.s.l. The described territory and adjacent Zone I of the Bavarian Forest National Park (Bavarian Forest NP) make up an area of ca. 5,000 ha in total that has been subjected to the same regime of management for a longer time, i.e. to spontaneous development.

\section{Methods}

As the basic map representing the vegetation cover of the territory a forest type map of the National Park and Šumava Protected Landscape Area (PLA) from 2003 (updated in 2005) was used. The typological units of forest vegetation used in the study correspond to the types of forest vegetation shown in Table 1.
Aerial photographs of sufficient quality were obtained from the administration of the Bavarian Forest $\mathrm{NP}$, where the whole territory of the national park was regularly photographed with spectrozonal camera (bands 4-3-2, i.e. G, R, NIR - near-infrared) or RGB camera (3-2-1). Aerial photographs were always taken in autumn from 1991 to 2000.

The source aerial photos were scanned at sufficient resolution (1,200 dpi) and then transformed by means of identical points (15-20 points per photo). Second-order polynomial transformation was used for this processing (cf. Žídek 2003).

After the identical points were found in the raster that is oriented by coordinates (it is mostly an orthophotomap) and in the unanchored raster (in an aerial photo in our case), the order of transformation to coordinates was determined (the order gives the power of a transformation function for the conversion of each point of the transformed raster). Taking into account the relief of the territory concerned, i.e. upland without pronounced fluctuations of the altitude, a second-degree polynomial was chosen for this purpose. For the described process the TopoLx T 9.5 software was used.

Other photos were processed by the method of orthorectification when based on the knowledge of so called ground control points and digital terrain model, an orthophotomap was constructed in the given coordinate system from source aerial photos.

Potential errors in aerial photographs (in most cases the presence of clouds in parts of the territory) were minimized in subsequent calculations and the missing values of digitized areas were interpolated from the values of the other years.

Every year a stand area with dead tree layer (ADTL) was set out by hand digitization (hand editing). In digitization single dead trees were omitted because their number and distribution on the area seemed insignificant for a description of the disinte-

Table 1. An overview of forest type groups (FTG) represented in the territory of interest

\begin{tabular}{|c|c|c|c|}
\hline FTG & Scientific name & English name & $\begin{array}{l}\text { Unit of Zurich-Montpellier } \\
\text { vegetation classification }\end{array}$ \\
\hline $8 \mathrm{Y}$ & Piceetum saxatile & Skeletal spruce stand & Calamagrostio villosae-Piceetum vaccinietosum \\
\hline $8 \mathrm{M}$ & Piceetum oligotrophicum & Oligotrophic spruce stand & Calamagrostio villosae-Piceetum vaccinietosum \\
\hline $8 \mathrm{~K}$ & Piceetum acidophilum & Acidic spruce stand & Calamagrostio villosae-Piceetum \\
\hline $8 \mathrm{~N}$ & Piceetum lapidosum acidophilum & Stony acidic spruce stand & Dryopterido dilatatae-Piceetum \\
\hline $8 \mathrm{~V}$ & Acereto-Piceetum humidum & $\begin{array}{l}\text { Waterlogged spruce stand with sycamore } \\
\text { maple }\end{array}$ & Athyrio alpestris-Piceetum \\
\hline $8 \mathrm{P}$ & Piceetum variohumidum acidophilum & Acidic gleyed spruce stand & Calamagrostio villosae-Piceetum sphagnetosum \\
\hline $8 Q$ & Piceetum variohumidum oligotrophicum & Waterlogged oligotrophic spruce stand & Equiseto-Piceetum/Mastigobryo-Piceetum \\
\hline $8 \mathrm{~T}$ & Piceetum paludosum oligotrophicum (humilis) & Stunted waterlogged spruce stand & Sphagno-Piceetum/Mastigobryo-Piceetum \\
\hline $8 \mathrm{G}$ & Piceetum paludosum oligomesotrophicum & Waterlogged spruce stand & Equiseto-Piceetum/Mastigobryo-Piceetum \\
\hline $8 \mathrm{R}$ & Piceetum turfosum montanum & Bog spruce stand & Junco filiformi-Sphagnetum recurvi/Sphagno-Piceetum \\
\hline $9 R$ & Mughetum turfosum & Dwarf pine bog & Oxycocco-Empetrion hermaphroditi/Pinion mughi \\
\hline
\end{tabular}


gration phase. A group of minimally 5 dead trees was considered as the focus of disintegration.

To describe the augmentation of the tree layer disintegration it was crucial to determine the maximum extent of augmentation of ADTL borders in the particular parts of the territory during the frontal infestation of spruce bark beetle, which was estimated in this way:

- The year 1997 was determined as year with the greatest augmentation of ADTL, i.e. the augmentation by 350.28 ha $(26.9 \%$ of the total area of the territory; Fig. 3).

- Along the borders of digitized ADTL from the previous year (1996) a series of buffers $20 \mathrm{~m}$ in width was created until these areas composed the ADTL from 1997.

- This area that originated by the buffering of 1996 ADTL was trimmed by the 1997 ADTL layer.

- Subsequently, from an attribute table of the newly created layer the values of maximum augmentation of the ADTL border were determined - the values of the maximum buffer after the application of above-described trimming.

- In the 1997 ADTL layer after the particular areas were determined, the maximum ADTL size was determined and the value of maximum augmentation of the ADTL border was found out for it.

- After identification of the source ADTL from 1996 it was possible to determine the direction and orientation of this augmentation.

To assess the relationship between the disintegration of Norway spruce stands and climatic characteristics, the data from hydrometeorological stations of the Czech Hydrometeorological Institute at Churáňov, Kvilda, Rokytecká sla and Březník (the area of Šumavské pláně including the investigated area) from 1984-2000 were used, namely air temperature, precipitation and snow cover.

Differences in the dynamics of disintegration between waterlogged stands (9R, 8R, 8G, 8N) and drier stands $(8 \mathrm{Y}, 8 \mathrm{M}, 8 \mathrm{~K}, 8 \mathrm{~V}, 8 \mathrm{P}, 8 \mathrm{Q}, 8 \mathrm{~T})$ were tested by the non-parametric Mann-Whitney U test.

Simple linear regressions were used to test the relationship between the dynamics of general disintegration and climatic parameters (average temperatures for each month of the year, each quarter of the year, average annual temperature, temperature in the growing season and outside the growing season, average precipitation for each month of the year, the sum of precipitation for each quarter of the year, average annual precipitation, the sum of precipitation in the growing season and outside the growing season, and Lang's rain factor). One-sample Student's t-tests were performed to test all the above-mentioned climatic parameters against long-term standard values from the period 1961-1990.

\section{Results}

\section{Description of mountain spruce stand disintegration}

After a detailed analysis the annual augmentation of ADTL was mapped in the particular years (see Table 2 and Fig. 2 and 3). At the same time exact measurements were done of the area of the territory concerned, areas of particular forest type groups (FTG) and annual changes in ADTL augmentation:

- total area of the territory concerned 1351,20 ha,

- total area of forest land (mapped by FTG units) 1325,22 ha,

- total area of timber land 1303,20 ha.

The graph of the annual augmentation of areas with spruce dead standing trees that originated after bark beetle outbreaks documents the period from 1991 to 2000. An increase in the proportion of dead standing trees in 1992 and 1993 was very similar to that in 1991, therefore their more pronounced increase in 1994 was included in the graph. Maximum annual augmentation of the area with dead standing trees obviously occurred in 1997, when it amounted to 350 ha. The phase of mountain spruce stand disintegration represented in this way demonstrates that at least in the studied territory the main frontal infestation of spruce bark beetle lasted for five years. However, gradual decline of Norway spruce mature trees lasted for more than 15 years in this territory. Currently, there are solitary surviving mature spruces there.

\section{Decline of forest stands from 1991 to 2000 by forest type groups (FTG)}

Significant differences were revealed by an analysis of the augmentation of areas with dead trees in the particular FTG in the particular years expressed as the ratio of the stand area with dead tree layer to the total area of a given FTG (Fig. 4).

The fastest disintegration was observed in FTG 8Y (already in 1995), i.e. at the most extreme (highly skeletal) sites. Waterlogged spruce stands (8P) were

Table 2. Annual changes in the areas with dead trees in the territory concerned

\begin{tabular}{lrrrrrrrrrr}
\hline \multicolumn{1}{c}{ Year } & 1991 & 1992 & 1993 & 1994 & 1995 & 1996 & 1997 & 1998 & 1999 & 2000 \\
\hline ADTL (ha) & 12.25 & 34.68 & 68.52 & 120.51 & 259.19 & 459.15 & 809.43 & 971.80 & 1013.15 & 1035.45 \\
$\begin{array}{l}\text { \% of the total area of } \\
\text { the territory }\end{array}$ & 0.94 & 2.66 & 5.26 & 9.24 & 19.89 & 35.23 & 62.11 & 74.57 & 77.74 & 79.45 \\
\hline
\end{tabular}



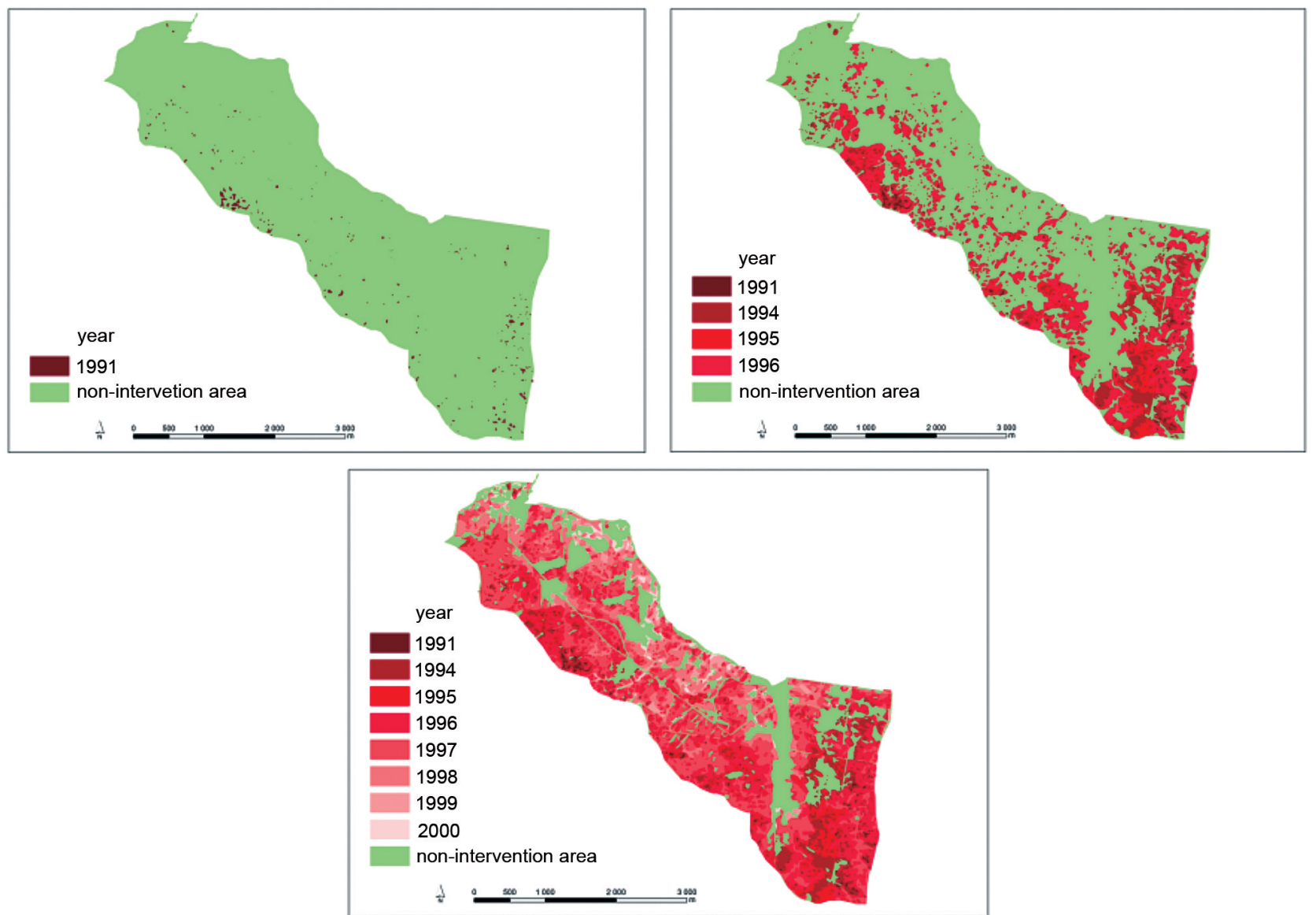

Fig. 2. Digitized areas with dead trees - augmentation of these areas in 1991-2000 against the situation in 2007

another significantly damaged forest type group, i.e. the sites that are periodically waterlogged but that often desiccate in some periods. Spruce stand disintegration took place at the majority of the other sites in a similar way between 1995 and 1997. In that period the most frequently represented acidic spruce stands underwent almost completely the phase of disintegration that culminated in 1997 (when disintegration was observed on ca. $70 \%$ of their area). A later onset of disintegration (shifted toward 1997 to 1999) was recorded at heavily waterlogged sites (8G, 8R and 9R).

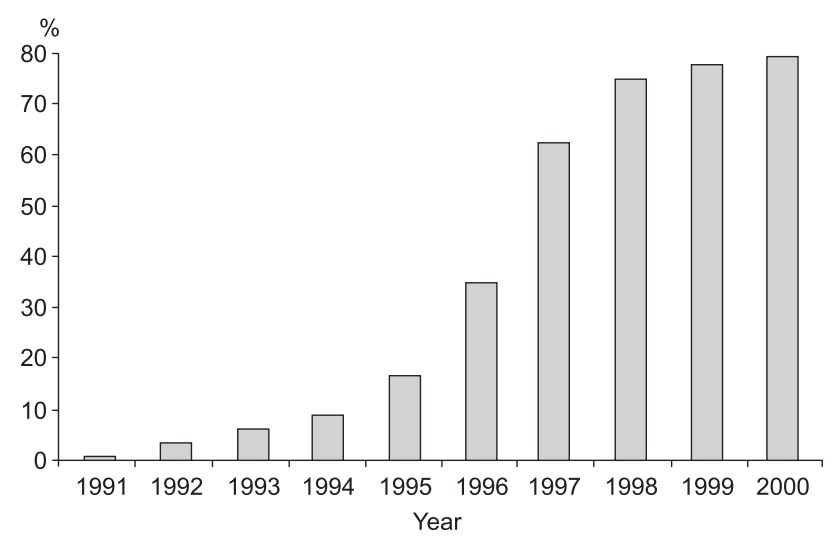

Fig. 3. Augmentation of areas with dead and dying trees in $\%$ of the timber land area
Stands in drier forest habitat types showed a significantly higher proportion of degraded area already in the second year of monitoring (1992) and this difference lasted till 1996 (Mann-Whitney U test for each year, $\mathrm{P}<0.05)$. Since 1997 the proportion of degraded area in drier and waterlogged stands was similar (Fig. 5).

\section{Annual rate of bark beetle infestation}

The longest distance in the provable frontal augmentation of the stand area with dry trees (killed by the feeding of spruce bark beetle) in west to east direction over a year was estimated to be $120 \mathrm{~m}$ per year. This annual distance was mostly hard to determine exactly because the neighbouring smaller ADTL attacked by bark beetle merged into each other, i.e. various so called satellite vanguards increased their density and augmented regardless of the main directions of infestation. This is the reason why based on data from aerial photos the average value of this distance was estimated to be $40-60 \mathrm{~m}$ per year in the studied period of the spruce bark beetle expansion.

However, this type of dead tree augmentation was preceded by an increase in the occurrence of individual affected trees (their number was negligible in our 


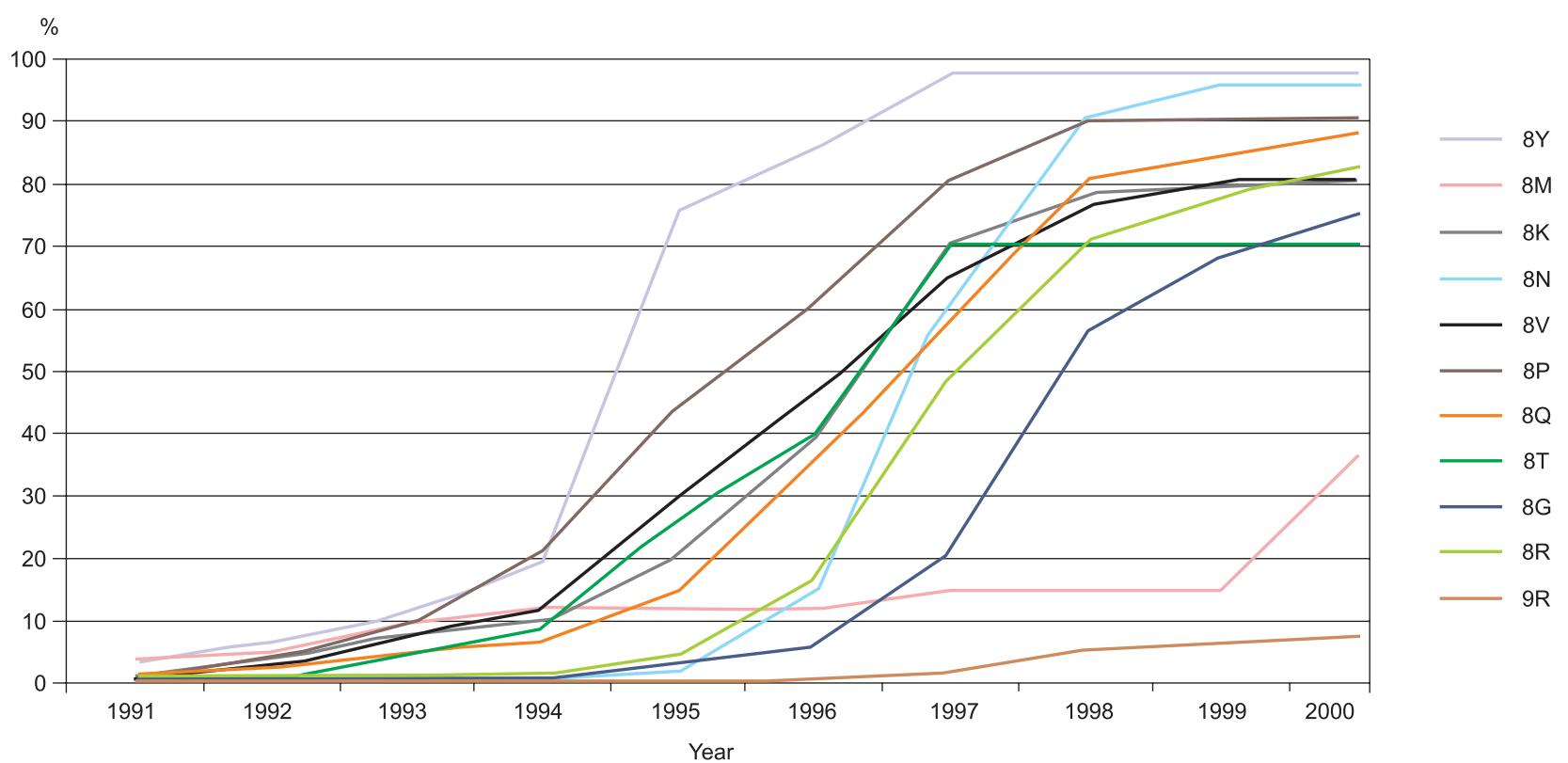

Fig. 4. Augmentation of areas with the dead tree layer of Norway spruce in $\%$ of the stand area in relation to FTG

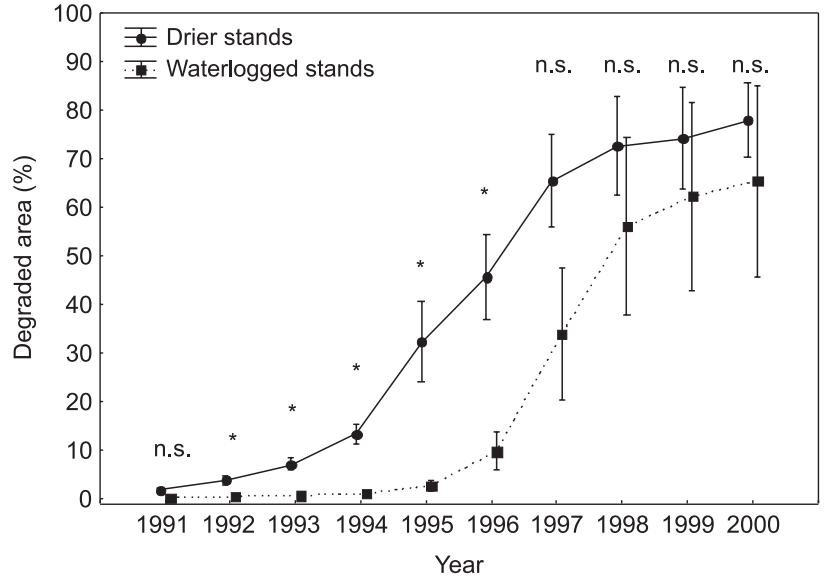

Fig. 5. The dynamics/the trend of area degradation in forest habitat types affected by water table and in drier stands. Vertical bars indicate standard error of the mean. N.s. indicates non-significant difference and *indicates statistical difference at a $\mathrm{P}<0.05$ significance level between stands in the given year, tested by the Mann-Whitney $\mathrm{U}$ test

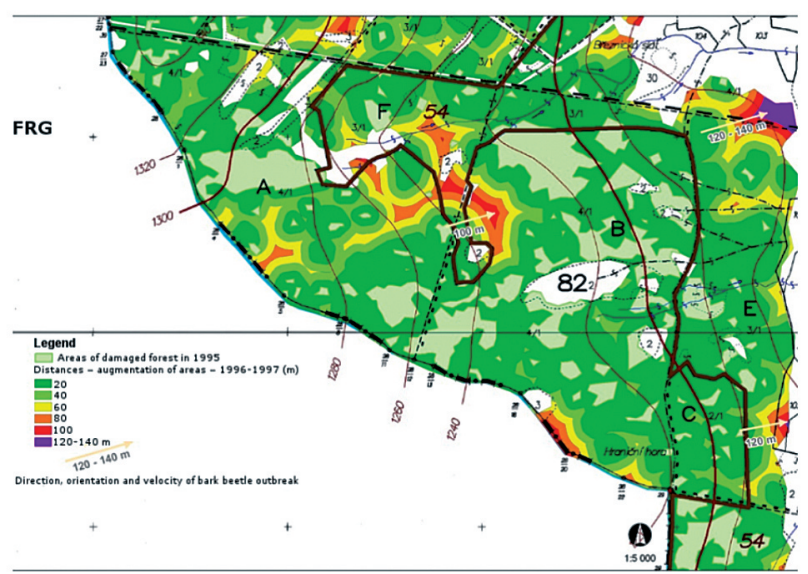

Fig. 6. Velocity of the frontal augmentation of areas with dead and dying trees (during outbreak in 1995-1997) case) and mainly by the appearance of new bark beetle foci of different size. A maximum distance of the appearance of new foci from the known source was estimated to be $380 \mathrm{~m}$ in the $1^{\text {st }}$ year (Fig. 6).

\section{Influence of climate on the onset of bark beetle outbreak}

The objective of the analysis was to detect the values registered in spring or winter months that could influence the normal character of winter or spring. All other known influences (acid precipitation deposition, inappropriate management of water regime, etc.) were gradually excluded. After simple verification of the list of minimum and maximum air temperatures we detected a significantly different course of air temperatures at a station situated just in the territory concerned. Over ten years the course of temperatures in January 1993 was distinctly different. Unexpectedly, the weather was warm from $7^{\text {th }}$ to $24^{\text {th }}$ January 1993, when the maximum air temperature rose to $+12^{\circ} \mathrm{C}$ and the minimum temperature did not fall below zero or was zero for several days. The snow cover became discontinuous for 5 days. The assimilatory apparatus of spruce was probably damaged by winter desiccation at that time as a result of high radiation and low soil temperatures.

Average monthly temperatures recorded in the period 1991-2000 did not generally differ from long-term normal values (period 1961 - 1990) with some exceptions: average temperature in January was higher $\left(-2.7^{\circ} \mathrm{C} \pm 1.5^{\circ} \mathrm{C} \mathrm{SD}, \mathrm{N}=10, \mathrm{t}=2.9, \mathrm{P}=\right.$ $0.017)$ than the long-term normal $\left(-4.1^{\circ} \mathrm{C}\right)$ and average temperature in August was higher $\left(13.9^{\circ} \mathrm{C} \pm\right.$ $\left.1.3^{\circ} \mathrm{C} \mathrm{SD}, \mathrm{N}=10, \mathrm{t}=3.7, \mathrm{P}=0.004\right)$ than the long-term normal $\left(12.4^{\circ} \mathrm{C}\right)$. Similarly, average monthly precipitation recorded in the investigated 


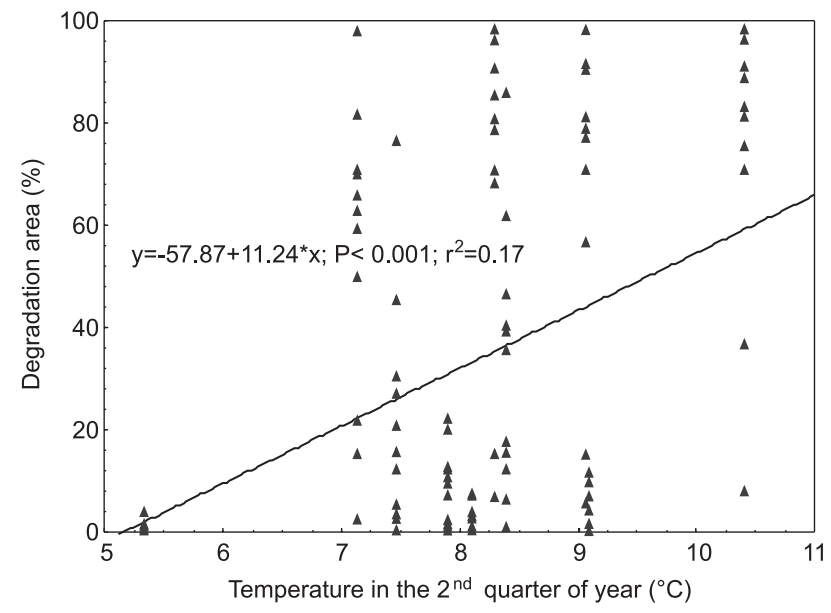

Fig. 7. A relationship of average temperatures in the $2^{\text {nd }}$ quarter of the year (from April to June) to the proportion of degraded area in the investigated period 1991-2000

period did not differ from long-term normal values (period 1961-1990) with the exceptions of April $(61.9 \mathrm{~mm} \pm 8.7 \mathrm{~mm} \mathrm{SD}, \mathrm{N}=10, \mathrm{t}=-2.8, \mathrm{P}=0.021)$ and August $(87.3 \mathrm{~mm} \pm 34.2 \mathrm{~mm} \mathrm{SD}, \mathrm{N}=10, \mathrm{t}=$ $-2.6, \mathrm{P}=0.028)$ with lower precipitation than the long-term normal (April: $86 \mathrm{~mm}$; August: $115.6 \mathrm{~mm}$ ).

There was a positive relationship between the average temperature in the $2^{\text {nd }}$ quarter of monitoring years and the proportion of degraded area in Norway spruce stands (Fig. 7), which is the period of the onset of bark beetle development.

\section{Discussion}

The intensity of bark beetle activity oscillated over time: the first bark beetle outbreak connected with stand disintegration lasted for 5 years and culminated in 1997 (cf. Vacek et al. 2003), the second great outbreak of bark beetle occurred after the Kyrill storm in 2007 (cf. Vacek, Krejčí et al. 2009). In normal conditions the probability of a local outbreak can be minimised by taking appropriate sanitation measures (Skuhravý 2002; Fahse and Heurich 2011); nevertheless after the onset of bark beetle outbreak sanitation measures do not usually reduce the progress of infestation significantly (cf. Jakušet et al. 2003; Kautz et al. 2011).

The relatively exact description of the phase of spruce stand disintegration caused by bark beetle disturbance is of strategic importance for the future planning of mountain spruce stand management in the Šumava Mts. Such a general disintegration of spruce stands is conditioned by the interplay of several factors (cf. Pfeffer and Skuhravý 1995). Considering that in the conditions of autochthonous mountain spruce stands of central Europe the stage of disintegration roughly occurs on a quarter of the stand area (cf. Jaworski 1998), it is an unusually large extent of disintegration, probably caused by long anthropogenic influences (forest management, effect of air pollution on the health status of spruce stands) in the studied forest ecosystems and in their proximate environs. The actual weather conditions played a crucial role in this case as they significantly differed from the current climatic characteristics of the territory (climatically extreme January 1993 with large differences in daily temperatures) as well as the presence of 2-3 extensive bark beetle foci in the proximity of the frontier in the Bavarian Forest NP (Skuhravý 1997). The disintegration per se was caused by the very fast onset of spruce bark beetle infestation. The outbreak was already observed in 1994 (i.e. a year after) in waterlogged spruce stands $(8 \mathrm{P}, 8 \mathrm{~V})$, which were probably debilitated physiologically by winter desiccation. The largest annual augmentation of areas with dry spruces occurred in 1997. In 1998 there was a decrease in the annual augmentation of ADTL and subsequently, it stopped similarly rapidly like its onset began. We showed that new infestations were predominantly found at short distances from their source, the average value was estimated to be 40-60 $\mathrm{m}$, whereas the longest distance for annual progress in west to east direction was estimated to be $120 \mathrm{~m}$. A maximum distance of the appearance of new foci from the known source was estimated to be $380 \mathrm{~m}$ in the $1^{\text {st }}$ year. These results are in accordance with Kautz et al. (2011), who estimated that on average $65.7 \%$ of new infestations were located within a radius of $100 \mathrm{~m}$ and almost all infestations occurred within a distance of $500 \mathrm{~m}$.

Yet, acquired knowledge of the dynamics of mountain spruce stand disintegration cannot be applied generally, nor can it be applied in other localities of the Šumava Mts. The general decline of stands in non-autochthonous spruce forests at lower altitudes was roughly more rapid. In addition, in the environs of the described area trees attacked by bark beetle were cut on a large scale in 1996-2000, also in the zone of mountain spruce stands. For this reason, the course of this disturbance cannot be evaluated exactly although some places, where the recession of described infestation is currently evident (a locality near Březník) have been preserved. In this evaluation all triggering conditions should be considered (Skuhravý 2002).

Pronounced winter desiccation in January 1993 could be a triggering mechanism in this case. Damage to the spruce assimilatory apparatus by winter desiccation as a result of high radiation and low temperatures of soil in comparable conditions was described by Tranquillini (1979) and others. It was a period when trees gave off a huge amount of water through transpiration but the roots in frozen or very cold soil (below $3^{\circ} \mathrm{C}$ ) could not take up water (cf. Vacek et al. 2007, Vacek et al. 2012). Such trees and stands are se- 
verely debilitated and highly vulnerable to bark beetle disturbance.

For a similar purpose Hais and Kučera (2008) created for the studied territory extrapolated values of air temperatures at a height of $2 \mathrm{~m}$ in three stages of the month of January in 1993. At the beginning of the month $\left(1^{\text {st }}-5^{\text {th }}\right.$ Jan. $)$ the daily average values were below zero $\left(-7.8^{\circ} \mathrm{C}\right)$, then a considerable warming occurred on $7^{\text {th }}-24^{\text {th }}$ Jan., when the daily average air temperature was $1.4^{\circ} \mathrm{C}$ and in the period from $25^{\text {th }}$ to $31^{\text {st }}$ Jan. the temperatures fell to the daily average of $-2.6^{\circ} \mathrm{C}$ again. These data in connection with high radiation document that pronounced winter desiccation took place in that period, i.e. forest stands suffered from obvious debilitation.

The development of the health status of the studied spruce stands and bark beetle outbreak were probably influenced by weather conditions and by a change in site characteristics (a drop in groundwater level, processes of introskeletal erosion) already at the time of stand disintegration (cf. Vacek et al. 2009). The years 1990-2011 showed a number of deviations. It was particularly the years 1992, 1994, 2000, 2003 and 2011 with Lang's rain factor 167.8; $166.5 ; 171.6 ; 163.3$ and 145.5 , respectively, in comparison with the normal value from the years 1961-1990 (261.8). Great acceleration of bark beetle infestation occurred at the end of the pronouncedly dry three-year period 1992-1994. It was the beginning of severe damage to the studied spruce stands. On the stand area $64 \%$ of trees died between the years 1995 and 1998, while in 1991-2000 it was 79\%. Another $4 \%$ of the area with the spruce tree layer died in the climatically extreme year 2003 (markedly above-normal temperatures and below-normal precipitation). In the given region ca. $2 \%$ of spruce trees (higher than $3 \mathrm{~m}$ ) were not attacked by bark beetle as to 2011, particularly in frequent frost pockets in FTG $8 \mathrm{R}$. On the remaining $15 \%$ of the stand area there was either no Norway spruce at all (FTG 9R) or only the initial juvenile stage or sparse seeding banks.

Hence the mesoclimate character has changed in the territory concerned in recent years. Besides an increase in average temperatures it is especially a decrease in rainfall in the period from April to June, which is the most important period for growth of trees. In general, in the Šumava Mts. a considerable drop in the groundwater table can be observed in the last several tens of years. It is reflected in a drop in the water table in previously heavily waterlogged forest site types (the drop is evident particularly in the edaphic category P, G, T, Q and R). Water deficiency in the soil in the first half of the growing season may disturb a number of physiological processes of spruce that finally result in a reduction in tree resistance to stress factors. It is another factor that may contribute to the outbreak of subcortical insects, i.e. of the spruce bark beetle (cf. Skuhravý 2002).

A far deeper and more detailed analysis should be carried out in the future focused on the parameters of particular stand groups differentiated by FTG, not only in the Šumava Mts. but also in other forests of the Czech Republic that have been severely attacked by different species of bark beetles. E.g. in the area of acidic spruce stands there existed large differences in the quality of particular stand groups. Large differences were observed in age, stocking, mean height and stem diameter, as well autochthonous origin of spruce trees in the Krkonoše Mts. (cf. Vacek and Lepš 1987, 1996). The highest recorded annual frontal augmentation of ADTL was observed in forests with declining allochthonous spruce stands with low stocking and apparently influenced by pasture in the past. As reported by Overbeck and Schmidt (2012), the stand parameters: age and proportion of spruce, and site parameters: available water capacity, temperature sum and the topex-to-distance index have significant effects on the infestation risk of spruce stands. Due to frequent and longer-lasting periods of drought, it is likely that on many sites forest trees will undergo physiological weakening. Despite considerable differences between the various forest soils, this potential stress factor is likely to increase and will be only partly compensated by forest soil water storage (Overbeck et al. 2011).

\section{Conclusion}

Catastrophic destruction of stands in the studied area due to bark beetle infestation appears to be related to three main predisposing factors: bark beetle outbreak in the adjacent Bavarian Forest NP as result of severe windstorms affecting large parts of the $1^{\text {st }}$ zone, stress during an unfavorable climatic period in winter 1993 weakening the vitality of Norway spruce stands and long anthropogenic influences increasing the vulnerability to epidemic outbreaks of spruce bark beetle (large tracks of allochthonous spruce stands, changed tree species composition, air pollution). The most intensive disintegration occurred in a short period between the years 1994 and 1997, nevertheless the disintegration slightly differed according to site conditions represented by different forest type groups. The fastest disintegration took place in stands on extreme (dry, skeletal) sites and also on acidic gleyed sites where the soil is periodically subjected to waterlogging and possible desiccation.

\section{References}

Č́žková P., Svoboda M., Křenová Z. 2011. Natural regeneration of acidophilous spruce mountain forests in non-intervenion management areas of the 
Šmava National Park - the first results of the Biomonitoring project. Silva Gabreta 17: 19-35.

Fahse L., Heurich M. 2011. Simulation and analysis of outbreaks of bark beetle infestations and their management at the stand level. Ecological Modelling 222: 1833-1846. doi: 10.1016/j.ecolmodel.2011.03.014.

Flint C.G., McFarlane B., Müller M. 2009. Human Dimensions of Forest Disturbance by Insects: An International Synthesis, Environmental Management 43:1174-1186.

Hais M., Kučera T. 2008. Surface temperature change of spruce forest as a result of bark beetle attack: remote sensing and GIS approach. European Journal of Forest Research 127: 327-336.

Hájek F., Svoboda M. 2007. Assessment of bark beetle damage in the Trojmezná old-growth forest (Šumava NP) using automated classification of aerial photographs. Silva Gabreta 13(1): 69-81.

Heurich M., Ochs T., Andresen T., Schneider T. 2010. Object-orientated image analysis for the semi-automatic detection of dead trees following a spruce bark beetle (Ips typographus) outbreak. European Journal of Forest Research 129: 313-324.

Hofgaard A. 1993. Structure and Regeneration Patterns in a Virgin Picea abies Forest in Northern Sweden. Journal of Vegetation Science 4: 601-608.

Holeksa J. 2001. Coarse woody debris in a Carpathian subalpine spruce forest. Forstwissenschaftliches Centralblatt 120: 256-270.

Jakuš R., Grodzki W., Ježik M., Jachym M. 2003. Definition of spatial patterns of bark beetle Ips typographus (L.) outbreak spreading in Tatra Mountains (Central Europe), using GIS. In: Ecology, Survey and Management of Forest Insects. Mc Manus M., Liebhold, A. (eds.). USDA Forest Service, Proceedings of the conference GTR NE-311, pp. 25-32.

Jaworski A. 1998. Budowa, struktura i dynamika górnoreglowych borów świerkowych w Karpatech a metody postępowania hodowlanego. In: Struktura I dynamika górskich bórow świerkowych. Zeszyty Naukowe Akademii Rolniczej, Kraków. 332: 37-68.

Jeník J. 1998. Biodiversity of the Hercynian mountains of Central Europe. Pirineos 151/152: 83-99.

Kautz M., Dworschak K., Gruppe A., Schopf R. 2011. Quantifying spatio-temporal dispersion of bark beetle infestations in epidemic and non-epidemic conditions. Forest Ecology and Management 262: 598-608.

Korpel' Š. 1993. Dynamics of natural spruce forest in the Western Tatras on the example of the state nature reserve Kotlový Žlab. Zborník Prac o TANAP 33: 193-225.
Korpel' Š. 1995. Die Urwälder der Westkarpaten. Stuttgart, Gustav Fischer Verlag, 310 p.

Manion P.D. 1981. Tree Disease Concepts. New Jersey, Prentice-Hall, Englewood Cliffs, 399 p.

Matějka K. 1994. Monitoring of the forest status in the Czech Republic. Recent results and prospects. In: Investigation of the forest ecosystems and of forest damage. Lowland and submountain forests and monitoring of the forest status. Matějka K. (ed.). FGMRI, Prague, pp. 146-154.

Overbeck M., Schmitt M. 2012. Modelling infestation risk of Norway spruce by Ips typographus (L.) in the Lower Saxon Harz Mountains (Germany). Forest Ecology and Management 266: 115-125.

Overbeck M., Schmitt M., Fischer Ch., Evers J., Schulze A., Hövelmann T., Spellmann H. 2011. Ein statistisches Modell zur Regionalisierung der nutzbaren Feldkapazität von Waldstandorten in Niedersachsen. Forstarchiv 82: 92-100 (in German).

Otto H.J. 1994. Waldökologie. Stuttgart, Ulmer, 391 p.

Pfeffer A., Skuhravý V. 1995. Lýkožrout smrkový a jeho problematika I., II. [Spruce bark beetle - a review], Lesnická práce, $74(3 / 4): 21 ; 74(5): 8-10$ (in Czech).

Pouska V., Svoboda M., Lepšová A. 2010. The diversity of wood fungi in relation to changing site conditions in an old-growth mountain spruce forest, Central Europe. European Journal of Forest Research 129: 1-13.

Poznański R., Jaworski A. 2002. Nowoczesne metody gospodarowania $\mathrm{w}$ lasach górskich. Warszawa, Centrum Informacyjne Lasów Państwowych, $228 \mathrm{p}$.

Průša E. 1985. Die böhmischen und mährischen Urwälder - ihre Struktur und Ökologie. Verlag der Tschechoslowakischen Akademie der Wissenschaften, Prague, 577 p.

Saniga M., Schütz J.P. 2001. Dynamics of changes in dead wood share in selected beech virgin forests in Slovakia within their development cycle. Journal of Forest Science 47: 557-565.

Schmidt-Vogt H. 1985. Struktur und Dynamik natürlichen Fichtenwälder in der borealen Nadelwaldzone. Schweizerische Zeitschrift für Forstwesen 136(12): 977-944.

Schmidt-Vogt H. 1986. Die Fichte. Band II/1 Wachstum, Züchtung, Boden, Umwelt, Holz. Verlag Paul Parey, Hamburg, 563 p.

Skuhravý V. 1997. Národní park Šumava a lýkožrout smrkový [Šumava National Park and spruce bark beetle]. Planeta 4: 22-24 (in Czech).

Skuhravý V. 2002. Lýkožrout smrkový a jeho kalamity [Spruce bark beetle and its calamities], Prague, Agrospoj, 196 (in Czech).

Sofron J. 1980. Vegetation einiger auserlesener Hochmoore von Šumavské plánì. Folia musei re- 
rum natur. Bohemiae occidentalis, ser. bot. 1: $3-27$.

Svoboda M. 2005. Struktura horského smrkového lesa v oblasti Trojmezné ve vztahu $\mathrm{k}$ historickému vývoji a stanovištním podmínkám [The structure of mountain spruce forest in the locality Trojmezná in relation to its historical development and site conditions], Silva Gabreta 11: 43-62. (in Czech)

Svoboda M., Pouska V. 2008. Structure of a Central-European mountain spruce old-growth forest with respect to historical development. Forest Ecology and Management 255: 2177-2188.

Svoboda M., Fraves S., Janda P., Bače R., Zenahlíková J. 2010. Natural development and regeneration of a Central European mountain spruce forest. Forest Ecology and Management 260: 707-714.

Štícha V., Kupka I., Zahradník D., Vacek S. 2010. Influence of micro-relief and weed competition on natural regeneration of mountain forests in the Šumava Mountains. Journal of Forest Science 56: 218-224.

Tiede D., Lang S., Hoffmann Ch. 2006. Supervised and Forest Type-specific Multi-scale Segmentation for a One-level-representation of Single Trees. In: Proceedings of the $1^{\text {st }}$ International Conference on Object-based Image Analysis. Lang S., Blaschke T., Schöpfer E. (eds.) July 4-5, 2006 Salzburg, Austria.

Tranquillini, W. 1979. Physiological Ecology of the Alpine Timberline. Berlin, 137 p.

Vacek S. 1990. Analýza autochtonních smrkových populací na Strmé stráni v Krkonoších, [Analysis of autochthonous spruce populations in the locality Strmá stráň in Krkonoše Mts.]. Opera Corcontica 27: 59-103. (in Czech)

Vacek S. 2003. Minimum area of forest left to spontaneous development in protected areas. Journal of Forest Science 49: 349-358.

Vacek S., Lepš J. 1987. Changes in the horizontal structure in a spruce forest over a 9-year period of pollutant exposure in the Krkonoše Mountains, Czechoslovakia. Forest Ecology and Management, 22: 291-295.

Vacek S., Lepš J. 1996. Spatial dynamics of forest decline: the role of neighbouring trees. Journal of Vegetation Science 7: 789-798.

Vacek S., Hejcmanová P., Hejcman M. 2012. Vegetative reproduction of Picea abies by artificial layering at the ecotone of the alpine timberline in the Giant (Krkonoše) Mountains, Czech Republic. Forest Ecology and Management 263: 199-207.
Vacek S., Krejčí F., Matějka K., Podrázský V., Remeš J., Ulbrichová I., Zatloukal V., Simon J., Minx T., Jankovský L., Turčáni M., Lepšová A., Starý J., Viewegh J., Bednařík J., Malík K., Bílek L., Štícha V., Semelová V., Vokoun J., Mikeska M., Prausová R., Ešnerová J., Mánek J., Kučera A., Vojtěch O., Jakuš R., Kozel J., Malík V., Vojtíšek R., Baláš M. 2009. Lesní ekosystémy $\mathrm{V}$ národním parku Šumava [Forest ecosystems in Šumava National Park], Kostelec nad Černými lesy, Lesnická práce, 512 p. (in Czech).

Vacek S., Matějka K., Simon J., Malík V., Schwarz O., Podrázský V., Minx T., Tesař V., Anděl P., Jankovský L., Mikeska M. 2007. Zdravotní stav a dynamika lesních ekosystémů Krkonoš pod stresem vyvolaným znečištěním ovzduší [Health stand and dynamic of forest ecosystems in Krkonoše Mts. under the air pollution stress], Folia forestalia Bohemica. Kostelec nad Černými lesy, Lesnická práce, 4: 216 p. (in Czech).

Vacek S., Podrázský V., Matějka K. 2006. Dynamics of the health status of forest stands and its prediction on research plots in the Šumava Mts. Journal of Forest Science 52: 457-473.

Vacek, S., Simon J., Remeš J., Podrázský V., Minx T., Mikeska M., Malík V., Jankovský L., Turčáni M., Jakuš R., Schwarz O., Kozel J., Valenta M., Lička D., Hlásny T., Zubrik M., Krejčí F., Třešňák J., Hofmeister Š. 2007. Obhospodařování bohatě strukturovaných a přírodě blízkých lesů, [Management of structurally differentiated and close-to-nature forest stands], Kostelec nad Černými lesy, Lesnická práce, 447 p. (in Czech).

Vacek S., Zingari P.C., Jeník J., Vančura K., Simon J., Smejkal J. 2003. Mountain forests of the Czech Republic. Prague, Ministry of agriculture of the Czech Republic, 320 p.

Vrška T., Hort L., Odehnalová P., Adam D., Horal D. 2001. The Milešice virgin forest after 24 years (1972-1996). Journal of Forest Science 47: 255-276.

Zemek F., Heřman M., Klouda Z. 1999. Bark beetle calamity assessment from remotly sensed data, Silva Gabreta 3: 161-172.

Žídek V. 2003. Od analogových snímků k digitálním objektům, [From analog photographs to digital objects], Folia Universitatis Agriculturae et Silviculturae Mendelianae Brunensis: Facultas Silviculturae et Technologiae Ligni, Brno, Res Publica Bohemia, 159 p. (in Czech). 